In the Hull Botanical Laboratory, after a long series of rigid comparative tests of the various paraffin solvents in general use, it was found that xylol when carefully used gave uniformly better results than any other solvent. Cedar oil was rejected because it is almost if not quite impossible to eliminate the oil in the final stages of imbedding. It is true that hard material cuts somewhat better after cedar oil, but the same end may be attained in a far better way by soaking the imbedded material in water.

Chloroform was abandoned because in transferring from alcohol to chloroform it was found that, even when a much closer series than the one recommended by Professor MotTIER is used, some plasmolysis results. Also we have found that paraffin does not seem to penetrate the tissues as readily after chloroform as after xylol. These results should be expected when we remember that the specific density of chloroform is nearly twice that of either alcohol, xylol, or paraffin. In STRASBURGER's laboratory chloroform was practically abandoned for xylol about i5 years ago. We have in this laboratory preparations of root tips as well as of Lilium anthers showing reduction division, which, from the maker's name, we assume were made exactly as described by Professor Mottier. These preparations are certainly inferior to those in which xylol was used as a solvent. Dr. L. W. Sharp, one of the most successful workers in the peculiarly difficult field of modern cytological technique, always uses xylol as a solvent.

If all stages in cytological technique received equal care, published results would undoubtedly be in closer accord than they are at present.W. J. G. LAND, University of Chicago.

\title{
BESSEYOSPHAERA, A NEW GENUS OF THE VOLVOCACEAE
}

Two new species of the Volvocaceae were described by Powers ${ }^{2}$ without names or assignments to taxonomic positions. They were designated "first form of Volvox" and "second form of Volvox." The former was subsequently further described and named Volvox spermatosphaera. ${ }^{3}$ The "second form" is intermediate between Pleodorina and Volvox in the scale of differentiation, and its assignment to either genus would involve so great an extension of the conception of the

${ }^{2}$ Powers, J. H., New forms of Volvox. Trans. Amer. Mic. Soc. 27:123-149. 1907 .

$3 \longrightarrow$, Further studies in Volvox. Trans. Amer. Mic. Soc. 28:141-175. 1908. 
genus as to be undesirable. Its nearest affinity may be considered to be Pleodorina californica, originally described by the writer ${ }^{4}$ and more completely described by CHATton." I now propose to treat this "second form" as the type of a new genus, dedicated under the name Besseyosphaera, to the memory of the late Professor Charles E. Bessey.

This new genus is distinguished from Pleodorina chiefly by having the gonidia scattered among the vegetative cells, instead of being developed from all the cells of the reproductive area. It differs from typical Volvox in having no protoplasmic connections between the cells, and in the lateness of the first visible differentiation of the gonidia, which does not appear until after birth. A study, now in progress, of several species of Volvox collected in the Philippine Islands leads us to anticipate that species lacking the intercellular protoplasmic connections may be properly removed from Volvox, some ranking below and some above Volvox in the scale of development. One or more of these may prove to belong properly in the same genus with the subject of these notes. For the present, however, it is convenient to treat our new genus as monotypic. Taking as a basis the facts stated by Powers, ${ }^{6}$ and making assumptions which seem to be warranted by the use of the name Volvox for this organism, the following diagnosis is offered.

Besseyosphaera, gen. nov.-Body a hollow spherical "coenobium" of greenish biciliate cells which lie in the periphery of a gelatinous matrix surrounded by a common hyaline envelope. Gonidia developed from cells distributed among the vegetative cells. No intercellular protoplasmic filaments. Daughters born before differentiation of gonidia. Sexual reproduction not known.

B. Powersi, sp. nov.-Second form of Volvox, J. H. Powers, Trans. Amer. Mic. Soc. 27:140-144. pl. I4. figs. 19-24. 1907.-Number of cells in the body about Iooo ("often below," "seldom much above"). Maximum diameter of body about $2000 \mu$ (I800-2500 $\mu$ recorded). Vegetative cells about I $2 \mu$ in diameter; separated by $50-200 \mu$. Gonidia 1o or more to 78 or more; distributed in two-thirds or four-fifths of the surface of the body; differentiated in the daughters after birth. Daughters less than $I_{5} \circ \mu$ in diameter at birth. Sexual reproduction not known. Habitat not stated (presumably a fresh water pond in Nebraska, United States).-Walter R. Shaw, University of the Philippines, Manila, P.I.

\footnotetext{
${ }^{4}$ Shaw, W. R., Pleodorina, a new genus of the Volvocineae. Boт. Gaz. 19:279283. 1894 .

5 Chatton, E., Pleodorina californica à Banyul-surmer: son cycle évolutive et sa signification phylogénetique. Bull. Sci. Francè et Belg. 44:309-33I. I9I I.

${ }^{6}$ Loc. cit. 1907 .
} 


\section{$2 \mathrm{BHL}$ Biodiversity Heritage Library}

Shaw, Walter R . 1916. "Besseyosphaera, a New Genus of the Volvocaceae." Botanical gazette 61(3), 253-254. https://doi.org/10.1086/331765.

View This Item Online: https://www.biodiversitylibrary.org/item/109212

DOI: https://doi.org/10.1086/331765

Permalink: https://www.biodiversitylibrary.org/partpdf/223761

\section{Holding Institution}

Missouri Botanical Garden, Peter H. Raven Library

\section{Sponsored by}

Missouri Botanical Garden

\section{Copyright \& Reuse}

Copyright Status: Public domain. The BHL considers that this work is no longer under copyright protection.

This document was created from content at the Biodiversity Heritage Library, the world's largest open access digital library for biodiversity literature and archives. Visit BHL at https://www.biodiversitylibrary.org. 